\title{
English in Public Administration
}

\author{
Authors: Manica Danko, Mihaela Zavašnik Arčnik \\ Published by: Faculty of Administration \\ Number of pages: 158 \\ ISBN: 978-961-262-021-9 \\ First published: 2009 \\ Slavica Čepon \\ University of Ljubljana, Faculty of Economics \\ slavica.cepon@ef1.uni-lj.si
}

English in Public Administration is a coursebook for the first-year university study foreign language program in Administration at the Faculty of Administration, University of Ljubljana. The coursebook consists of a foreword that clearly states the authors' approach to the coursebook production, eight units and two mock exams with a key (after $U 4$ and $U$ 8) - useful signposts on the language learners' road to achieving learner autonomy. The authors' choice of the material for the eight units clearly shows that they have taken into account the fact that the graduates in administration have to be knowledgeable about different areas, such as economics, management, law, public finance, informatics, human resources etc. Hence, the topics Student of Public Administration, State, Government, Municipality and administrative unit, Judiciary, Parliament, The European Union and A Career in (EU) Administration.

The coursebook was created with a view to satisfying several key requirements. Firstly, the authors were clearly aware of the fact that the term 'public administration' in Slovenia encompasses a scope of various job positions and employments that need to be catered for by graduates from the Faculty of Administration. As they point out in the foreword, their main goal with the coursebook was to satisfy the practical language needs relevant to an extremely wide spectrum of employment possibilities that the graduates of the Faculty of Administration encounter in Slovenian reality.

Put simply, the coursebook is intended for a specific target group of foreign language learners, and is therefore based on their concrete language needs. The 
Slavica Čepon

Book Review: English in Public Administration

fact that the use of English in the coursebook is specific and associated with professions, institutional procedures and occupational requirements, makes it also an important source of learning material in the field of English for Specific Purposes (ESP). The authors have, as they emphasize in the foreword, based all the decisions as to content and teaching methods on the language learners' specific reasons for learning a foreign language. Their main orientations were need, relevance and usability (slov. potreba, relevantnost in uporabnost), i.e., satisfying the target group's language needs by producing a relevant and usable coursebook.

By and large, two features are usually thought to be criterial of ESP, firstly, its orientation toward learners' goals, and secondly, the necessity for performing the analysis of needs. In view of this, the coursebook meets both, since in 2006/07, prior to producing the coursebook; the authors performed a needs analysis that was taken as a basis for the subsequent coursebook production. The selection of reading comprehension texts in the coursebook is varied and carefully hand-picked according to the results of the target group of learners' needs analysis. The texts are always presented in expected, appropriate contexts. In addition, they are authentic, i.e., not created for pedagogical, language learning purposes in classrooms.

One of the reasons why the present coursebook can be categorized as modern and topical is the approach that the authors have chosen when selecting reading comprehension texts - they appear in the coursebook strictly according to two selection criteria: they must contain public administrationspecific vocabulary, and secondly, they must meet the public administration target group of learners' needs. Due to the fact that a variety of reading texts from the coursebook were taken from the everyday reality of native speakers of English, it is possible to assume that a life cycle of such texts, along with the coursebook, is going to be quite long.

To illustrate, the coursebook is full of useful topics and information for the public administration target group of foreign language learners, such as:

- language to do with working part-time as a student and paying income tax

- names of various institutions, ministries and types of courts in Slovenia

- names of civil servants' titles in Slovenian and English

- learning about the features of a state, the Slovenian Constitution, the Slovenian Parliament, the Slovenian National Council and National Assembly 
- language to do with the procedure of applying for citizenship or obtaining a residence permit in Slovenia

- information on the EU, its history, EU acronyms and jargon (e.g. EMU, OSCE, acceding state, acquis communautaire, subsidiary, enlargement etc.), the EU as a multicultural society

- key information about places to see in Slovenia, Slovenian food and drinks, the economy, accommodation, traditions and customs etc. when presenting Slovenia as a tourist destination

- language to do with reading a conference invitation, applying for and attending a conference abroad or in English.

- information on career prospects in the EU institutions in the EPSO leaflet

In practice, a potential source of difficulty when reading authentic texts could be the fact that foreign language learners are not always able to distinguish between useful, key public administration-specific vocabulary and less important vocabulary, i.e., between active and passive vocabulary. In the coursebook, this has been successfully dealt with via a quite simple device: the authors have decided to assist learners by adding a shorter, simplified English-English glossary, along with a Slovenian translation. By doing this, the authors have possibly extended the usefulness of the coursebook from a solely university program for language learners to less able language learners.

In terms of the logical organization of units, each unit progresses from the contextualized input in form of reading comprehension towards a more controlled, guided practice, leading the language learners step by step to production and understanding. Predictably, not just reading comprehension texts, also language learning activities and tasks that complement the texts and recycle the key vocabulary are ingenious and creative, chosen merely on the basis of their relevance to would-be public administration graduates. They appear to be personally engaging and reflexive (e.g. applying for citizenship, obtaining a residence permit in Slovenia, applying for and attending a conference, career prospects in the EU etc.). The activities and tasks also include work with mind-maps, gap filling, T/F, matching and transformation type of exercises. The learners are also encouraged to develop a variety of reading, dictionary and online strategies, such as to read between the lines, to follow the main idea in the text and to 
Slavica Čepon

Book Review: English in Public Administration

use different online databases for language learning purposes. From a wide range of potentially useful activities and tasks the following seem worth mentioning:

- writing e-mails, formal letters, letters of application and CVs

- writing abstracts (e.g. for a thesis) based on IMRAD structure

- a writing practice in the use of linking words

- frequent Latin expressions (e.g., i.e., etc., vs., ibid.)

- the use of numbers in speech and writing

- describing graphs, trends and movements

- learning English idioms

- a practice in distinguishing between pairs of similarly looking or sounding words (e.g. policy/politics, audit/revision, incur/occur etc.)

Since experts in the language learning field have again started recommending the use of a mother tongue for foreign language purposes the topical trends in modern foreign language coursebook production are clearly evident also in the authors' decision to devote a good deal of language learning activities and tasks to translating from Slovenian to English and vice versa with an emphasis on public administration-specific vocabulary (e.g. slov. biti zavezan zakonu, odložilni veto, člen, odstavek, alineja, določba, uredba etc.). It is common knowledge that such activities may be potentially difficult for language learners, so the authors have opted for an inclusion of suggestions for easier work in the instructions. For instance, they may remind the students of the key vocabulary from the unit or suggest using dictionary entries from the coursebook unit (p. 5, p. 12, p.59, p. 83). However, all the translations do not carry such instructions, so the coursebook sometimes presupposes foreign language teachers input assistance in order to enable language learners to take full advantage of translations as language learning activities.

The coursebook mainly focuses on covering the four skills, both expressive and receptive, and language structures while there is practicaly no work on language functions. The most covered skill is reading, the least dealt with is listening. A point worth mentioning here are glossaries not just after reading but also before listening activities (e.g. p.26) to introduce the context and attune the learners for listening comprehension.

It is highly commendable that the coursebook also incorporates listening comprehension and watching videos/films to cater for various cognitive variations in human learning, also referred to as learning styles. Most certainly, this is a quality 
that must make the coursebook particularly appealing to a young generation of language learners. However, the adequacy, appropriacy and relevance of the proposed listening materials cannot be fully evaluated on any other basis but their effect and the corresponding reaction that they evoke in the classroom. In a similar vein, the learning materials intended for e-learning cannot be evaluated due to the fact that they have not been included in the coursebook.

In terms of structures, vocabulary is paid more attention to than grammar. Equally, also grammar topics selection procedure clearly shows the signs of striving to be public administration specific. The learners are presented with the following grammatical choices:

- passive voice

- word formation exercises (including prefixes and suffixes)

- expressing contrast

- modal verbs (esp. the use of 'shall' to indicate obligation and 'may' for permission in legal documents)

- infinitival and gerundial constructions

- phrasal verbs

- conditional clauses

- and very little work with prepositions, tenses and, collocations.

As a rule, grammar is not first presented, then practiced and finally produced - this fact shows that the authors have not opted for a traditional 'PPP approach' on purpose. Apparently, their aim was to produce a different, motivating and fresher coursebook. Grammar does not even appear in each unit, and is dealt with lightly and with minimum input.

Overall, we could safely conclude that the main appeal of the coursebook for the target learners lies in its relevance to learners' future professions, that is in its public administration-specific orientation, both in terms of the authors' choice of topics, and language content and language learning activities. Moreover, the coursebook's appeal for a young target group of learners is provided by watching videos and films, by being able to work with databases for language learning purposes, by being offered glossaries in the coursebook and not having to look up the words in the dictionaries, to mention but a few. Anyway, to make the coursebook really learner-friendly and to encourage 
Slavica Čepon

Book Review: English in Public Administration

learner autonomy, we suggest that the coursebook should include a key to all its exercises, not just to two mock tests.

In view of all the above, it seems as if one of the potential shortcomings of the coursebook could be the fact that certain activities appear to be quite exacting. For instance, explaining differences between words such as 'incomerevenue-earnings' or 'insure-assure-ensure' and others (p. 8/ex. 4), reading the UK Civil Service Code (pp. 40-42), translating the text into Slovenian about seeking asylum (p. 89), translating the text into English about advertising Slovenia in National Geographic Traveler (p.125), summarizing a Slovenian text in English (p.144) or watching a film about European Court of Human Rights ( $p$. 81). The truth of the matter is that in practice there are never enough dictionaries available in any classroom to use for such an activity. Given the fact that most language learners in the first-year foreign language program in Administration at the Faculty of Administration have not yet reached really high levels of foreign language knowledge such activities would need to be approached with caution: they would either need teacher intervention in the classroom or learners' pre-preparation work before classes.

In addition, we feel that there could be more emphasis on listening/watching/speaking skills, as well as more use of color, pictures and visual stimuli since incorporating and utilizing a variety of methods and tools is the key to becoming proficient at English. Coursebooks are the traditional way to study, however foreign language students cannot hope to become good listeners without practicing listening. A great resource and a valuable aural tool could be an inclusion of a CD to be used in the classroom or at home.

Another suggestion for improving the listening skill emphasis in the coursebook are also second language prerecorded audio/video podcasts (also netcasts) available online in varying levels, also free. Typically, these audio/video podcasts are recorded by native speakers so they are a great way to practise listening to native speakers. They cover a wide variety of topics, from basic to more advanced subjects, and are easy to find at the appropriate level (e.g. http://digitalpodcast.com/). Most are updated regularly and several include written transcripts of the podcasts so students can read along. Moreover, they are quite short and therefore more learner- and teacher-friendly in comparison with quite long listening ativity about European Court of Human Rights (p. 81).

Since the coursebook is intended for 60 hours' teaching time certain reading and writing activities seem rather long. The assumption is that they may take up too much classroom time without the pre-preparation phase at home. 
Taking into consideration all the coursebook's aspirations, its features, advantages and possible pitfalls, the coursebook English in Public Administration appears to be a motivational coursebook, appropriate for the target group of public administration language learners to whom it speaks without talking down.

In conclusion, let us remember that teaching/learning a foreign language as a whole is not viable, therefore only certain aspects of a foreign language have to be selected by teachers and learners to focus on. Incredibly, the authors have accomplished just that - in the form of the coursebook English in Public Administration they have given us their view of what a successful selection of learning materials based on a target group's language needs should be like. Eventually, however good the coursebook, it will never be perfect for every teacher's teaching situation, and in some respect it will always need adapting, modifying or supplementing. In case of listening/watching activities and e-learning materials this is only good, since nowadays any possible shortcomings may be remedied in no time. 